\title{
Discussion on British and American literature teaching mode in quality-oriented education
}

\author{
Hongyan Guan \\ Xi'an University, Xi'an, 710065, China
}

Keywords: Quality-oriented education, British and American literature, Existing problems, Solutions.

\begin{abstract}
In English teaching, British and American literature can play a teaching effect of broadening view and improving humanistic quality on the basis of obtaining vocabularies and grammar. Quality-oriented education calls for students' comprehensive development, thus carrying out British and American literature teaching is an objective requirement for English teaching in quality-oriented education. But we should also see that although quality-oriented education has been conducted for years, some schools blindly focus on theoretical education for improving enrollment rate so that British and American literature is not valued without being included into the exam range. Thus, exploring the method of optimizing British and American literature education under quality-oriented educational background is of great application value.
\end{abstract}

\section{Introduction}

British and American literature classes are set for students to learn western culture and the cultural development history by means of reading classics and watching movies so as to realize the improvement of their literature accomplishment on the basis of broadening students' view. In recent year, with the deepening and promotion of Chinese education reform, there is a growing call of satisfying students' individualized development. The teaching mode of British and American literature should keep up with the time for reform so as to adapt to the current teaching requirements. The article has firstly elaborated some issues existing in current British and American literature teaching. Then on the basis of analyzing the significance of British and American literature teaching, the article has proposed several suggestions on optimizing British and American literature teaching under quality-oriented educational background.

\section{Issues existing in current British and American literature}

\section{Lack of great attention to British and American literature teaching}

The effect of British and American literature teaching work is directly related to degree of emphasis from teachers. In everyday teaching, English as a main subject, it accounts for higher scores in examination. To help students achieve satisfactory performance in exams, teachers should focus more on grammar and other theoretical knowledge education intentionally. British and American literature contents should be as students' personal interest. They can read British and American literature materials after class by themselves but lack uniform arrangement and professional guidance. In such case, students are under great learning pressure so that they have no sufficient time to participate into British and American literature study, which results in their bad learning effect. On the other hand, due to the lack of careful guidance from teachers, they cannot obtain timely solution when meeting difficulties and thus lose interest for continuous exploration due to the great difficulty. Therefore, the shift of teachers' teaching focus is the direct reason preventing British and American literature teaching work from being effectively carried out. 


\section{The teaching mode needs to be optimized and perfected}

For a long time, English classroom teaching is with teacher as the subject so that students can only passively receive teachers' theoretical instillation with no teacher-student interaction. Under such a teaching mode, teachers cannot get any teaching feedback from students so that they can only formulate teaching plan based on the teaching program. As British and American literature course is not included into the range of exam, it is hard to attract teachers' attention when formulating teaching plan.

\section{English teachers' literature accomplishment are of varying levels.}

Students will inevitably meet confusions and problems when learning British and American literature, thus teachers' professional quality and literature level will directly influence the teaching effect of British and American literature. According to the present situation, most English teachers' literature accomplishment cannot satisfy literature teaching requirements.

\section{Influence of British and American literature teaching on students' quality-oriented education}

A lot of English teachers believe that students can only provide guarantee for literature learning after mastering a solid English foundation. This viewpoint is reasonable but it works only for English beginners. When students have accumulated a certain amount of vocabularies and mastered some basic grammar, they can automatically read British and American literature materials or books with the help of dictionaries or other auxiliary means. Practical investigations show that carrying out literature teaching at the same time of English language teaching can realize the complementary to each other. In other words, through British and American literature teaching, students can improve their English learning interest and improve classroom learning efficiency. Except for teaching facilitation, British and American literature has brought about different profound impact on students' quality-oriented quality education.

\section{It can help students to understand exotic culture and expand their view}

Literature as a language learning tool contains poem, novel, prose and other different genres from the perspective of art form. Since from modern times, with the emerging of different media, many stage drama and movie have become a new form of British and American literature. Literature in any forms have contained a nation's excellent ideology and culture as the comprehensive expression and overall summary of the national politics, society, and economy. Thus, when reading British and American literature works, students can feel the customs, life habits and historical background of western countries, and also feel the unique charm of British and American culture while experiencing the fierce collision between oriental and occidental cultures, so as to stimulate students' exploration interest, and expand personal view in continuous study, and enrich personal knowledge. It plays a promoting role for English language learning and it is also of great benefits for students' future growth and development.

\section{It can improve students' aesthetic taste and strengthen literature accomplishment}

Words and sentences in literature works are obtained through authors' repeated deliberation, extraction and processing. Especially for some typical and classical literature works, Students can directly experience the strong expressive force of literature works during the process of reading and appreciation.

Students can feel the author's writing background through words across time and space so as to realize the reading effect of emotional resonance with the author for the purpose of further improving personal literature appreciation level and strengthening language organization and expressive ability. It is a long process for students to develop and improve their literature accomplishment requiring for a certain culture deposit and strong appreciation ability. Carrying out British and American literature teaching can provide a channel for students to improve their literature attainment. 


\section{Strengthen students' critical thinking skills and enrich personal emotion}

Literature has another important role of improving students' critical thinking ability except for improving language ability and cultural cognition level. In addition, it can enrich personal emotions when reading some excellent British English and American literature works. For example, when reading "The merchant of Venice", students can learn how to make choices in front of friendship and money; when reading "Pride and Prejudice", students will be impressed by the leading character's acts of daring to fight and pursuing freedom. Literature works are with irreplaceable infectivity and education effect, helpful for students to cultivate taste and expand mind. Due to the richness of literature language, diversity of literature genre, and the depth of literature ideology, literature has become effective material to cultivate students' thinking ability. The criticism methods of British and American literature is to make instance analysis on specific literature works by applying the theory of literary criticism, which can help improve students' theoretical attainment and critical thinking ability. Students can actively participate in discovering, finding and creating text meanings through reading British and American literature works, so as to develop acute sense and master rigorous analytical methods gradually and finally establish accurate expression methods. Students will benefit greatly through elevating the rich perceptual experience to a conceptual knowledge based feeling, analyzing and expressing ability.

\section{Measures to improve British and American literature teaching quality in quality-oriented education}

\section{Optimize teaching contents and reasonably arrange courses}

Firstly, based on the literature theoretical absence in current literature class teaching, teachers should stress the introduction of literature common sense when instructing literature works, add more introduction of the theory of literary criticism, school and terms, and update the obsolescent, and outdated viewpoints. Secondly, except for asking students to recite some graceful, elegant and short proses to improve students' basic literature attainment, teachers should combine literature work read-up with life issue through intensive analysis and instruction so that students can feel life philosophy and elevate life realm to promote students to actively and innovatively read literature works and profoundly comprehend the rich connotation of literature works when feeling elegant languages. At last, teachers should appropriately and alternatively conduct British and American literature teaching in everyday education. Combination of literature works and teaching materials can improve the richness of teaching contents and also cultivate students' literature accomplishment unconsciously, to achieve the teaching effect of double benefits.

\section{Change teaching concept and value literature teaching}

Firstly, based on students' concept formed in exam-oriented education, teachers should impart students with the importance of literature interior value step by step so that they can know that literature is of great benefit in improving a person's overall quality and forming good values. Secondly, teachers and professional researchers engaged in this aspect should take the initiative to change concepts, abandon previous viewpoint that literature teaching is full of text analysis, knowledge instillation and teachers' “one voice class”, and text analysis starts from thinking contents, writing features and other procedures in a stereotyped way. The teaching contents and teaching method of British and American literature class should adhere to the principle of improving students' humanistic quality and cultivating their creative thinking.

British and American literature class should focus on cultivating students' cognitive ability, innovation and practical ability. Students' innovative quality include innovative awareness, innovative spirit, innovative ability and innovative personality, involving the individual's originality of problem-finding, sensitivity of problem-judging, accuracy of problem-analyzing and efficiency of problem-solving. Thus, it is necessary to emphasize the combination of intelligent factors with non-intelligent factors in British and American literature teaching mode for students' comprehensive 
development especially the role of non-intelligent factors (including willpower, emotion, interest, quality and personality) in education process.

\section{Reduce teachers' scientific and research pressure and improve teachers' literature quality}

To guarantee British and American literature teaching quality, teachers should get well prepared for teaching preparation work, especially when using multi-media. Except for combing students' reading interest and English proficiency to prepare for literature works, teachers should read through the work ahead of time and download some information relevant with works form the internet such as author's introduction, and video materials. These preparation work will take up teachers' working time. From the perspective of teachers, many teachers will exert partial energy to scientific research or academic paper for the purpose of conferring of academic titles, which will inevitably take up a part of work time. Besides, teachers must prepare for daily teaching materials and prepare for classes, deal with superior's teaching inspection. Thus, their work schedule is tense. In such case, teachers can only weigh the advantages and disadvantages, shorten the time for British and American literature preparation. In practical teaching, some English teachers carry out British and American literature appreciation classes without nothing prepared and courses contents conducted by students' autonomous reading.

For this phenomenon, from the perspective of schools, they should optimize teachers' evaluation model and increase teachers' promotion channels so as to reduce teachers' scientific research pressure and spend more time and energy for teaching preparation to guarantee British and American literature teaching quality. From the perspective of teachers, they should make reasonable allocation of work time to guarantee the sufficient time of preparing British and American literature teaching; on the other hand, they should improve personal literature quality and read more British and American literature work after work so as to improve personal quality and recommend suitable literature works to students in practical teaching.

\section{Make full use of multimedia assisted teaching tools}

In the era of "Internet +", Assisted teaching with the support of multi-media has become a mainstream form for English classroom teaching. As multimedia can dynamically display the static contents in books, it is well received by students. Thus, teachers should focus on reasonably using multimedia while conducting British and American literature so as to provide assistance to cultivate students' literature quality while stimulating students' classroom interest and improve classroom teaching efficiency. Teachers should pay attention to highlight the application advantage of multimedia to guarantee literature teaching effect.

For example, use contents not mentioned in literature books through multimedia to help students comprehensively understand literature works. After reading "The Adventures of Tom Sawyer”, students will be touched by the leading character's spirit of fighting and pursuing freedom, and also will experience the darkness of American Society in the 19th century. Students have no complete understanding of the author Mark Twain even they have a basic knowledge of the literature work contents. In such case, teachers can use multimedia to play the author's life stories, anecdotes and art characteristics, so that students can have a deeper understanding of the writing background for the purpose of emotional elevation and literature quality improvement.

\section{Conclusion}

Oscar Wilde wrote in his work "The Critic as Artist" that, Literature always predicts the life, instead of imitating life, but to shape life based on one's own purpose. British and American literature works may originate from real life or reflect current social background. When learning and appreciating British and American literature works, students should start from the literature work itself to understand the contents. They should also combine with the writing background to have an in-depth understanding of the deep value of literature work and author's rich emotion. In this way, the effect of "fruitful reading" can be achieved, which is the essential purpose of carrying out British and American literature teaching in English classroom teaching. 


\section{Reference}

[1] Zhang Qi. Analysis on the feasibility of "flipped classroom" teaching mode in British and American literature teaching”, Journal of Lanzhou College of Education, 2017, 33(4), pp.85-87.

[2] Li Yuewen, Chen Yuanyuan. Improvement and innovation of advanced English course teaching method--Take the fifth and sixth volume of "Contemporary College English Intensive Reading” as the example,College English Teaching and Research, 2013, (1), pp.3-6.

[3] Li Yinghua. Effect of cultural background on English intensive reading--Take "Contemporary College English Intensive Reading” (Volume 2) as the example, Global Market Information Guide , 2014,(15), pp.128-128.

[4] Wei Lanting. Penetration of British and American literature knowledge in English major intensive reading course---Take "Contemporary College English (2nd version) Intensive 3), Journal of Heihe University, 2017, (3), pp.66-67. 